\title{
Effect of amphotericin $B$ and gestational age on sodium transport across the rat visceral yolk sac placenta in vitro
}

\author{
J. S. Gibson and J. C. Ellory \\ The Physiological Laboratory, University of Cambridge, Downing Street, Cambridge CB2 $3 E G$, \\ U.K.
}

\begin{abstract}
Summary. The transport properties of the rat visceral yolk sac placenta from Days 14.5 to 18.5 of gestation were studied in vitro. All tissues had a positive potential difference, fetal side relative to maternal side, and showed net $\mathrm{Na}$ transport towards the fetus. Basal short-circuit current and net $\mathrm{Na}$ flux increased rapidly with gestational age over the period studied. Amphotericin B applied to the maternal surface of the yolk sac stimulated current and net $\mathrm{Na}$ flux, indicating that the apical membrane $\mathrm{Na}$ permeability limited transport and revealing a reserve capacity for transport. Contrary to their basal values, current and $\mathrm{Na}$ flux following treatment with amphotericin were independent of gestational age.
\end{abstract}

\section{Introduction}

The rat visceral yolk sac provides an additional site for transfer between the fetal and maternal circulations, augmenting the usual mammalian (chorioallantoic) placenta (see Text-fig. 1). In the early stages of development, the rat embryo is dependent on the yolk sac, while in late gestation the placenta is pre-eminent. Thus the yolk sac is an important organ of exchange during organogenesis - as shown by the ability to culture embryos in vitro over this period under conditions in which nutrition cannot be supplemented by the placenta (New, 1978). In addition, there is a suggestion of a complementary relationship between the yolk sac and the placenta, with differential transport of dyes (Everett, 1935) and divalent cations (Wislocki, Deane \& Dempsey, 1946).

Established functions of the yolk sac include the uptake of proteins and their subsequent selective transport or degradation (see Freeman, Beck \& Lloyd, 1981) and transfer of immunoglobulins late in gestation (Brambell \& Halliday, 1956). The yolk sac is important in the consideration of teratogenesis, either as a potential site of teratogen action or in terms of barrier function (Turbow, 1966; Beck, 1982). However, there is relatively little information available on other transport properties of this tissue, despite its importance to the developing embryo.

In the context of salt and water transport, the only previous substantive work in the literature is the study of Chan \& Wong (1978) which established the late (17-5- to 21-5-day) yolk sac as an invitro preparation. We have extended their findings recently (Ellory \& Gibson, 1984) using 14.5-day tissues mounted in a specially designed Ussing chamber (Gibson, 1983). The present study represents an examination of $\mathrm{Na}$ transport in tissues from conceptuses of various gestational ages, and demonstrates the effect of development on salt transport.

\section{Materials and Methods}

Animals and dissection. Rats were kept under standard laboratory conditions. Females were placed with males overnight and fertilization was assumed if vaginal smears, taken on the following morning, contained spermatozoa (Day $0 \cdot 5$ ). When at the required stage of gestation, females were 
killed by cervical dislocation, the abdomen opened and the gravid uterus removed. After removal from the uterus, the conceptuses were kept in aerated saline (see below) at $38^{\circ} \mathrm{C}$ until use. Yolk sacs were separated from the other fetal membranes, Reichert's and the amniotic membranes (Text-fig. 1), and, after dissection, pinned to the removable cassette of the Ussing chamber (for details see Gibson, 1983) which was then inserted between the two half-chambers. Half-chamber volume was about $0.8 \mathrm{ml}$ and temperature was maintained at $38^{\circ} \mathrm{C}$ by circulating fluid through the water-jacket of the chamber. The area of exposed tissue could be varied between 0.3 and $0.8 \mathrm{~cm}^{2}$.

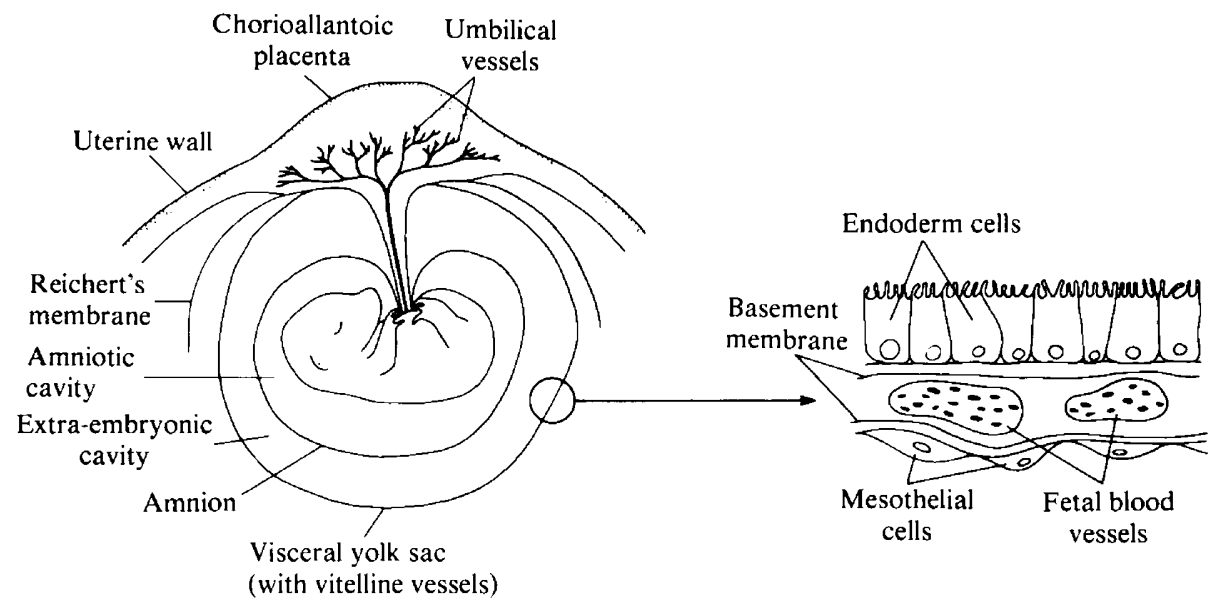

Text-fig. 1. Schematic diagram showing the arrangement of fetal membranes in an early rat embryo (with part of Reichert's membrane removed (a), and detail of the visceral yolk sac epithelium, (b)).

The saline, Krebs-Ringer-bicarbonate, had the following composition, in $\mathrm{mM}: \mathrm{NaCl} 118, \mathrm{KCl}$ 4.7, $\mathrm{MgSO}_{4} 1 \cdot 17, \mathrm{CaCl}_{2} 2 \cdot 56, \mathrm{NaHCO}_{3} 25, \mathrm{NaH}_{2} \mathrm{PO}_{4} 1 \cdot 13$, D-glucose 10 and L-alanine 2, and was bubbled continuously with $95 \% \mathrm{O}_{2} / 5 \% \mathrm{CO}_{2}$ and adjusted with Tris to give a pH of 7.4 at $38^{\circ} \mathrm{C}$.

Electrical measurements. All experiments were performed under short-circuit conditions using a conventional voltage-clamp. Transepithelial potential difference (p.d., $\mathrm{mV}$ ) is expressed as the potential of the maternal side subtracted from the potential of the fetal side and was measured using calomel electrodes connected to the Ussing chamber via 3\%agar-saline bridges ending about $2 \mathrm{~mm}$ from each side of the tissue. An external current was injected via a pair of $\mathrm{Ag} / \mathrm{AgCl}$ electrodes and agar-saline bridges to short-circuit the p.d. to zero. Current is given in $\mu \mathrm{A} . \mathrm{cm}^{-2}$, positive if flowing from the fetal to the maternal side. Resistance of the solution between the two voltage electrodes was compensated for automatically by the voltage-clamp apparatus. In practice, all tissues had a positive p.d. and a negative current.

Sodium flux measurements. Isotopic tracer fluxes of ${ }^{24} \mathrm{Na}$ and/or ${ }^{22} \mathrm{Na}$ were used to measure the unidirectional Na flux. All results for 14.5-day tissues were obtained using simultaneous bidirectional fluxes; ${ }^{24} \mathrm{Na}$ was used for maternal-to-fetal side fluxes $\left(\mathrm{J}_{\mathrm{MF}}\right)$, and ${ }^{22} \mathrm{Na}$ for fetal-tomaternal side fluxes $\left(\mathrm{J}_{\mathrm{FM}}\right)$ on the same tissue. At other gestational ages separate unidirectional ${ }^{22} \mathrm{Na}$ fluxes were sufficient to measure the net flux and were carried out on paired fetal tissues from the same mother and giving similar currents. To measure the bidirectional $\mathrm{Na}$ flux, ${ }^{24} \mathrm{Na}$ was used at $37-74 \mathrm{kBq} \cdot \mathrm{ml}^{-1}$ on the maternal side, with ${ }^{22} \mathrm{Na}$ at $3 \cdot 7-7 \cdot 4 \mathrm{kBq}$ on the fetal side. Solutions were changed every $15 \mathrm{~min}$ using a double-barrelled syringe to obviate any pressure difference across the tissue. Stability of the preparation was improved by this latter precaution. ${ }^{24} \mathrm{Na}$ appearing in the fetal solution $\left(\mathrm{J}_{\mathrm{MF}}\right)$ was counted immediately in a Packard Autogamma scintillation spectrometer 
and again after the decay of ${ }^{24} \mathrm{Na}$ to assess and then subtract the contribution of ${ }^{22} \mathrm{Na}$ to the total counts. Similarly, following ${ }^{24} \mathrm{Na}$ decay, ${ }^{22} \mathrm{Na}$ was counted after addition of $3 \mathrm{ml}$ scintillant, PicoFluor ${ }^{\mathrm{TM}} 30$, in a Packard Tricarb scintillation spectrometer. Unidirectional fluxes of ${ }^{22} \mathrm{Na}$ were counted, as above, using scintillant.

Both isotopes were obtained from Amersham International (Bucks, U.K.).

Amphotericin. Amphotericin was used as a saturated solution at $20 \mu \mathrm{g} \cdot \mathrm{ml}^{-1}$ and was obtained as Fungizone ( $50 \mathrm{mg}$ amphotericin, $41 \mathrm{mg}$ sodium desoxycholate buffered with $20.2 \mathrm{mg}$ sodium phosphate: E. R. Squibb \& Sons, Inc., Princetown, NJ 08540, U.S.A.). Amphotericin is an ionophore acting on sterol-containing membranes to increase their permeability to small solutes, especially univalent ions (Lichtenstein \& Leaf, 1965), including $\mathrm{Na}$ (e.g. Rose \& Nahrwold, 1976). Maternal application of amphotericin causes intracellular $\mathrm{Na}$ of the yolk sac cells to reach electrochemical equilibrium with $\mathrm{Na}$ in the bathing medium and hence its concentration will rise markedly. Transport of $\mathrm{Na}$ across the basolateral membrane will be stimulated if apical membrane $\mathrm{Na}$ permeability, and thence intracellular $\mathrm{Na}$ concentration, was previously limiting. Under these conditions, the rate of $\mathrm{Na}$ pumping should be limited only by the density of $\mathrm{Na}$ pumps in the basolateral membrane or possibly by the ATP availability.

Statistics. Results are expressed as the mean \pm s.e.m. of $n$ observations. Comparisons are made by Student's $t$ test.

\section{Results}

Initially, the data on electrical and flux studies on tissues from 14.5-day animals are presented in detail. Subsequently, tissues from different gestational ages are compared in terms of current and $\mathrm{Na}$ fluxes.

\section{Tissues from 14.5-day conceptuses}

The time course of current changes in 14.5-day tissues, mounted in vitro, is presented in Text-fig. 2. It is clear that 14.5-day tissues gave a stable current and p.d. over $1 \mathrm{~h}$, as shown, but in other experiments, tissues continued to give stable values for at least $3 \mathrm{~h}$. When ouabain $\left(10^{-4} \mathrm{M}\right)$ was applied to the fetal (or basolateral) side the current and p.d. fell rapidly to zero (Text-fig. 2), a result expected from the similar findings of Chan \& Wong (1978) for the 19.5-day tissue. In conventional terminology for epithelia, therefore, the maternal side is apical and the fetal side is basolateral. Maternal ( = apical) application of amphotericin $(20 \mu \mathrm{g} / \mathrm{ml})$ produced prompt stimulation of current, to values initially about 10 -fold that of the control (or basal) values (Text-fig. $2 \mathrm{~b}$ ). The transient peak was followed by a decrease to a more stable level, about 5 times the control, by 30 min after addition of amphotericin. This current, like that in basal conditions, was ouabainsensitive: similar stimulation of the current by amphotericin was not seen after prior treatment with ouabain to the fetal side. The transepithelial resistance, given by p.d./current, was about $350 \Omega$ $\mathrm{cm}^{2}$ in basal conditions, tending to decrease after amphotericin to $250 \Omega \mathrm{cm}^{2}$ and increasing after ouabain to $>1000$.

Bidirectional isotopic $\mathrm{Na}$ flux data are shown in Table 1. The control net $\mathrm{Na}$ flux was $0.46 \pm$ $0.05 \mu \mathrm{mol} . \mathrm{cm}^{-2} \cdot \mathrm{h}^{-1}$ towards the fetus, a value about 2-3 times greater than can be accounted for by the current, expressed in $\mu$ equiv. $\mathrm{cm}^{-2} \cdot \mathrm{h}^{-1}$. Na transport, therefore, must be accompanied by the net movement of some other ion. With ouabain treatment, net $\mathrm{Na}$ flux was only inhibited by about $50 \%$ after $90 \mathrm{~min}$ to $0.24 \pm 0.04 \mu \mathrm{mol} . \mathrm{cm}^{2} \cdot \mathrm{h}^{-1}(n=5)$, despite the rapid effect on current (Text-fig. 2). Amphotericin caused a 4-fold increase in net $\mathrm{Na}$ absorption to $1.99 \pm 0 \cdot 23$ $\mu \mathrm{mol} . \mathrm{cm}^{-2} \cdot \mathrm{h}^{-1}(n=5)$. 


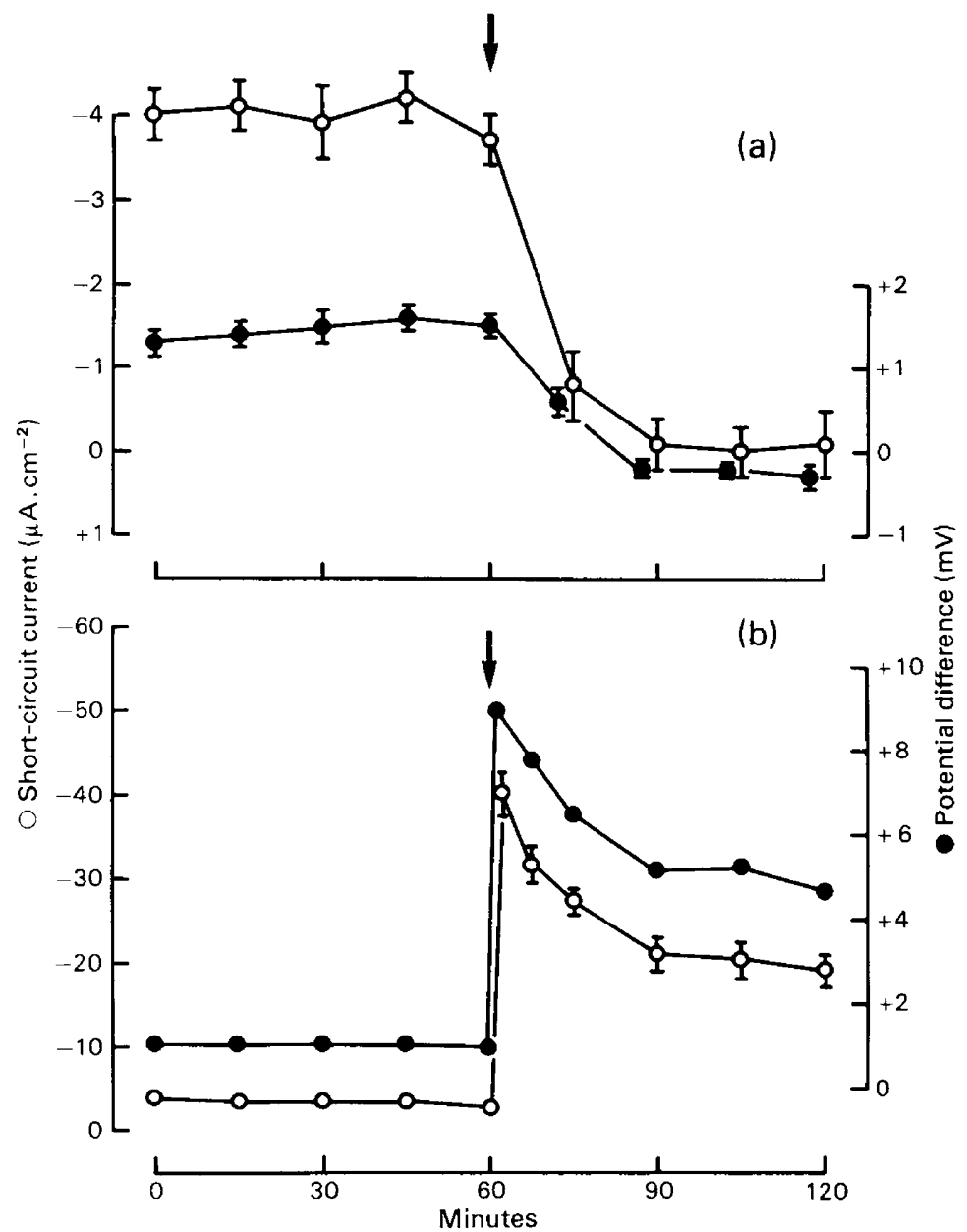

Text-fig. 2. Effect of (a) ouabain applied to the fetal side, and (b) amphotericin applied to the maternal side of the 14.5-day rat yolk sac on the short-circuit current and potential difference. Values are mean \pm s.e.m. for 5 observations.

Unidirectional flux data contained in Table 1 emphasize the large individual variation which necessitated the measurement of simultaneous bidirectional fluxes to reveal the small net $\mathrm{Na}$ flux at this gestational age. However, unidirectional fluxes do show that ouabain acted mainly by increasing $\mathrm{J}_{\mathrm{FM}}$, whilst amphotericin increased $\mathrm{J}_{\mathrm{MF}}$, presumably by stimulating the $\mathrm{Na}$ pump.

Table 1. Unidirectional $\mathrm{Na}$ fluxes in the yolk sac of the $14 \cdot 5$-day rat

\begin{tabular}{lcccc}
\hline & \multicolumn{4}{c}{$\mathrm{Na}$ flux $\left(\mu \mathrm{mol} . \mathrm{cm}^{-2} \cdot \mathrm{h}^{-1}\right)$} \\
\cline { 2 - 5 } & Control & $\begin{array}{c}\text { Ouabain }\left(10^{-4} \mathrm{M}\right) \\
\text { to fetal side }\end{array}$ & Control & $\begin{array}{c}\text { Amphotericin }(20 \mu \mathrm{g} / \mathrm{ml}) \\
\text { to maternal side }\end{array}$ \\
\hline $\mathrm{J}_{\mathrm{MF}}$ & $2.55 \pm 0.68(4)$ & $2.65 \pm 0.65(4)$ & $3.45 \pm 0.83(5)$ & $4.96 \pm 0.78(5)$ \\
$\mathrm{J}_{\mathrm{FM}}$ & $2.10 \pm 0.66(4)$ & $2.43 \pm 0.67(4)$ & $3.08 \pm 0.72(5)$ & $2.98 \pm 0.59(5)$ \\
\hline
\end{tabular}

Values are mean \pm s.e.m. for the no. of observations in parentheses. 


\section{Effect of gestational age on electrical values and $\mathrm{Na}$ fluxes}

The current as a function of gestational age (14.5, 15.5, 16.5, 17.5 and 18.5 days) is shown in Text-fig. 3. The results of Chan \& Wong (1978) have been added for comparison and completeness. The trend shown by these authors, peak current at 19.5-days decreasing at higher and lower ages, continued in our study over earlier gestational ages. The apparent discrepancy at 17.5 days is not significant $(P>0.1)$ and probably reflects either variability or the rapid rate of change of current with age, necessitating measurement at the same time of day for accurate comparison. Text-figure 3 shows that, from 14.5 days to 18.5 days, the control or basal current could more than double over a 2-day period.

Amphotericin $(20 \mu \mathrm{g} / \mathrm{ml})$ was applied to the maternal side of tissues from Days 14.5 to 18.5 and the resulting currents (averaged over the subsequent hour) are shown in Table 2. At every gestational age, amphotericin stimulated current, implying that all tissues have a reserve $\mathrm{Na}$ pumping capacity not expressed in the basal situation. However, the size of this reserve capacity diminished with gestational age: at 14.5 days amphotericin stimulated current by $500 \%$, whilst producing only a $35 \%$ stimulation at 18.5 days. Furthermore, the absolute current reached after amphotericin appeared to be the same from Days 14.5 to $18 \cdot 5$, despite the rising basal current.

The corresponding flux data are less complete (Table 2) but the trend shown is similar. For the three ages studied, flux after amphotericin was always about $2 \mu \mathrm{mol} . \mathrm{cm}^{-2} \cdot \mathrm{h}^{-1}$, whilst basal fluxes increased from 0.46 at 14.5 days to 1.20 at 16.5 days.

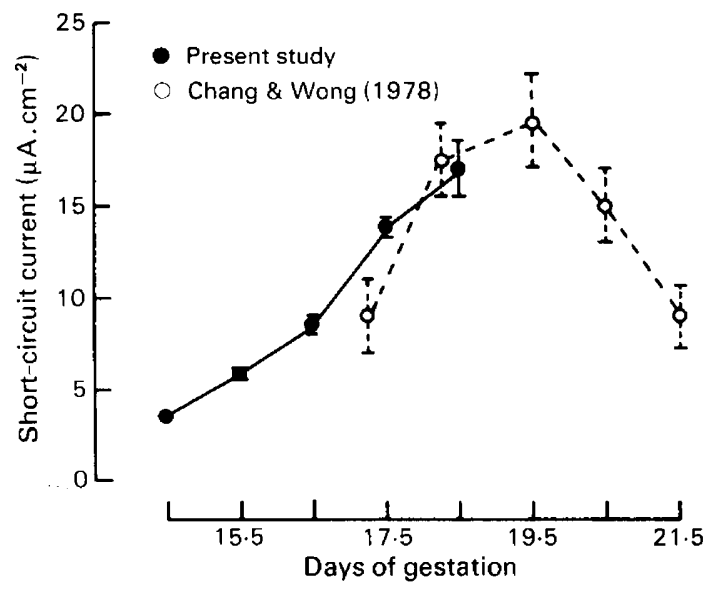

Text-fig. 3. Effect of gestational age on the short-circuit current of the rat yolk sac, values are means \pm s.e.m. for 6-11 observations. The data of Chan \& Wong (1978) are means \pm s.e.m. for 4-6 observations.

Table 2. Effect of increasing gestational age on short-circuit current $\left(\mu \mathrm{A} . \mathrm{cm}^{-2}\right)$ and net $\mathrm{Na}$ fluxes $\left(\mu \mathrm{mol} . \mathrm{cm}^{-2} \cdot \mathrm{h}^{-1}\right)$ under basal conditions and after maternal application of amphotericin

\begin{tabular}{|c|c|c|c|c|c|}
\hline & \multicolumn{5}{|c|}{ Day of gestation } \\
\hline & $14 \cdot 5$ & $15 \cdot 5$ & $16 \cdot 5$ & $17 \cdot 5$ & $18 \cdot 5$ \\
\hline \multicolumn{6}{|l|}{ Current } \\
\hline Control & $3.8 \pm 0.7(5)$ & $5.7 \pm 0.7(10)$ & $10 \cdot 0 \pm 1 \cdot 3(7)$ & $13.9 \pm 1 \cdot 1(6)$ & $17.0 \pm 3.3(8)$ \\
\hline Amphotericin & $24 \cdot 4 \pm 2 \cdot 6$ & $27 \cdot 5 \pm 1 \cdot 1(10)$ & $22 \cdot 7 \pm 2 \cdot 4(7)$ & $23 \cdot 7(1)$ & $22 \cdot 0(2)$ \\
\hline \multicolumn{6}{|l|}{ Net Na flux } \\
\hline Control & $0.46 \quad 0.05(11)$ & $0.07 \pm 0.21$ & $1.20 \pm 0.35(5)$ & & \\
\hline Amphotericin & $1.99 \pm 0.23$ & $2 \cdot 11 \pm 0 \cdot 34$ & $2 \cdot 15 \pm 0.33(2)$ & & \\
\hline
\end{tabular}

Values are mean \pm s.e.m. for the no. of observations in parentheses. 


\section{Discussion}

The present paper seeks to establish the role of the rat yolk sac in salt transport during development, and to characterize any developmental changes occurring in its function during mid- and late-gestation.

We show that 14.5-day tissues behave in a qualitatively similar way to those of 19.5 days (Chan $\&$ Wong, 1978). In both cases, net $\mathrm{Na}$ flux towards the fetus exceeds the short-circuit current. Chan \& Wong (1978) found that neither amiloride nor $\mathrm{Cl}$ replacement affected current, which suggests that the discrepancy does not result from $\mathrm{Na} / \mathrm{H}$ exchange or $\mathrm{NaCl}$ co-transport. However, both these processes are non-electrogenic and it might be difficult to establish their presence by current measurements. Clearly, further studies on these and other possible transport processes are necessary. The smaller effect of fetal application of ouabain on net $\mathrm{Na}$ fluxes when compared to that on current is sometimes seen in other tissues (Ramos \& Ellory, 1981) and could be due to a slow washout of $\mathrm{Na}$ from the tissue. The size of experimental error whilst measuring a very small flux will also contribute to an apparent ouabain-insensitive flux.

As gestation proceeds, basal net $\mathrm{Na}$ flux and current are seen to increase (Table 2; Text-fig. 3) but the possible regulatory mechanisms are unknown. The yolk sac could develop autonomously, with an intrinsic trigger affecting the basal properties, or an external signal, from either the mother or, more probably, the fetus, could be responsible. The culture of embryos in vitro $(\mathrm{New}, 1978)$ and the use of certain manipulations to produce selective death of the embryo whilst fetal membranes survive (e.g. culturing in high $\mathrm{CO}_{2}$; Beck, 1983) provide obvious systems on which to test these possibilities.

The role of this net $\mathrm{Na}$ flux towards the fetus is not known. From analogies with intestine and kidney, tissues which develop from the same germ cell layer, possible functions are water and nonelectrolyte transport (see Diamond \& Bossert, 1967; Schultz \& Curran, 1970). At present we know of no measurements of the $\mathrm{Na}$ dependence of water, glucose or amino acid fluxes. One can estimate the total volume that the rat yolk sac is able to transport (Table 3) assuming isotonic flow accompanying the $\mathrm{Na}$ flux, and compare this value with the increasing fluid volume in the conceptus (using data from Tam \& Chan, 1977). Na transport by the yolk sac is easily able to accommodate this volume. The apparent excess $\mathrm{Na}$ movement can easily be accounted for by hypertonic water flow or the need to replace water lost by some other mechanism, e.g. by a hydrostatic pressure difference across the yolk sac tending to keep it distended; a deficit would be harder to explain. However, a more specific role for $\mathrm{Na}$ is likely and, in this context, measurements of non-electrolyte fluxes in the presence and absence of $\mathrm{Na}$ would be of value.

Finally, the significance of stimulation of net $\mathrm{Na}$ flux and current by amphotericin should be considered. Amphotericin, in this case, has the principal effect of increasing apical membrane $\mathrm{Na}$

Table 3. An estimate of water transported by the rat yolk sac

\begin{tabular}{lccc}
\hline & $14.5-15.5$ days & $15.5-16.5$ days & $16.5-17.5$ days \\
\hline Change in conceptus volume* (ml/day) & 0.244 & 0.393 & 0.478 \\
Estimated yolk sac area† $\left(\mathrm{cm}^{2}\right)$ & 5.8 & 7.4 & 10.6 \\
Na flux towards fetusł $(\mu \mathrm{mol} /$ day) & 81 & 169 & 305 \\
Estimated volume transported $\S(\mathrm{ml} /$ day) & 0.54 & 1.12 & 2.03 \\
\hline
\end{tabular}

\footnotetext{
* Maximum change in conceptus volume between the 2 days, using data from Tam \& Chan $(1977)$, = $(\Delta$ wet wt of fetus - dry wt $)+(\Delta$ wet wt of placenta and membranes $)+(\Delta$ wt, extraembryonic fluid $)$.

$\dagger$ Estimated as the area of a sphere $2 r=1.3$ at 14.5 days, 1.4 at 15.5 days, 1.65 at 16.5 days and 2.0 at 17.5 days, in $\mathrm{cm}$. Area is averaged over the 2 -day period.

$\ddagger \mathrm{Na}$ flux towards fetus $=$ average $\mathrm{Na}$ flux over the 2 days $\left(\mu \mathrm{mol} . \mathrm{cm}^{-2} \cdot \mathrm{h}^{-1}\right)$ from basal values, in Table $2, \times 24 \times$ yolk-sac area.

$\S$ Volume transported, assuming $\mathrm{Na}$ concentration is $150 \mathrm{~mm}(\mathrm{Na}$ flux/150 in ml).
} 
permeability (Rose \& Nahrwold, 1976) and thence raising the intracellular $\mathrm{Na}$ concentration. Stimulation of current and net $\mathrm{Na}$ flux in these conditions indicates that the apical membrane $\mathrm{Na}$ permeability was previously limiting to $\mathrm{Na}$ pumping, and reveals a large reserve capacity for $\mathrm{Na}$ transport not expressed in basal conditions. The transient current could be caused by diffusion potentials being established across the intercellular junctions following the increased rate of $\mathrm{Na}$ pumping at the basolateral cell membrane. A contribution from a decreasing $\mathrm{Na}$ pump rate during this period is also possible. The extent of the reserve capacity for $\mathrm{Na}$ transport decreases with increasing gestational age. These results suggest the presence of a possible second regulatory mechanism, concomitant with the developmental changes occurring through gestation (see above). It would allow for the presence of hormonal control signals from the mother or, more probably, the fetus to adjust the yolk sac properties to that required, via action on the apical membrane permeability. One can envisage the advantage of such regulation acting as a fine control, perhaps when superimposed upon an automatic change in property of the yolk sac with gestational age. Further, it seems, from Table 2, that the maximum rate of $\mathrm{Na}$ transport by this tissue is independent of gestational age, although the basal flux increases with age. The results could be interpreted in terms of a fixed basolateral $\mathrm{Na}$ pumping capacity. They suggest that, during the developmental period studied in this paper, there is no change in $\mathrm{Na}$ pump density within the yolk sac tissue, whilst $\mathrm{Na}$ transport shows a considerable reserve, probably modulated at the level of apical $\mathrm{Na}$ permeability.

J.S.G. thanks the M.R.C. for financial support.

\section{References}

Beck, F. (1982) Lessons from studies in animals for the evaluation of human risk from teratogenic agents. In Advances in Pharmacology and Toxicology. II. Vol. 5 , Toxicology and Experimental Methods, pp. 17-28. Eds H. Yoshida, Y. Hagihara \& S. Ebashi. Pergamon Press, Oxford.

Beck, F. (1983) The use of the whole embryo culture of the rat in the experimental study of human birth defects. In Prevention of Spina Bifida And Other Abnormalities, pp. 23-51. Ed. J. Dobbing. Academic Press, London.

Brambell, F.W.R. \& Halliday, R. (1956) The route by which passive immunity is transmitted from mother to foetus in the rat. Proc. $R$. Soc. B. 145, 170-178.

Chan, S.T.H. \& Wong, P.Y.D. (1978) Evidence of active sodium transport in the visceral yolk sac of the rat. $J$. Physiol., Lond. 279, 385-394.

Diamond, J.M. \& Bossert, W.H. (1967) Standinggradient osmotic flow-a mechanism for coupling of water and solute transport in epithelia. J. gen. Physiol. 50, 2061-2083.

Ellory, J.C. \& Gibson, J.S. (1984) Sodium transport across the rat yolk-sac endoderm early in gestation. $J$. Physiol., Lond. 346, 84P.

Everett, J.W. (1935) Morphological and physiological studies of the placenta in the albino rat. J.exp. Zool. 70, 243-284.

Freeman, S.J., Beck, F. \& Lloyd, J.B. (1981) The role of the visceral yolk sac in mediating protein utilisation by rat embryos cultured in vitro. J. Embryol. exp. Morph. 66, 223-234.
Gibson, J.S. (1983) A simple Ussing-type chamber for studying transport in the yolk-sac placenta of the rat. J. Physiol., Lond. 343, $18 \mathrm{P}$.

Lichtenstein, N.S. \& Leaf, A. (1965) Effect of amphotericin B on the permeability of the toad bladder. J. clin. Invest. 44, 1328-1342.

New, D.A.T. (1978) Whole-embryo culture and the study of mammalian embryos during organogenesis. Biol. Rev. 53, 81-122.

Ramos, M.M.P. \& Ellory, J.C. (1981) $\mathrm{Na}$ and $\mathrm{Cl}$ transport across the isolated anterior intestine of the plaice Pleuronectes platessa. J. exp. Biol. 90, 123-142.

Rose, R.C. \& Nahrwold, D.L. (1976) Electrolyte transport by gallbladders of rabbit and guinea-pig: effect of amphotericin $\mathrm{B}$ and evidence for rheogenic $\mathrm{Na}$ transport. J. Membrane Biol. 29, 1-22.

Schultz, S.G. \& Curran, P.F. (1970) Coupled transport of sodium and organic solutes. Physiol. Rev. 50, 637718.

Tam, P.P.L. \& Chan, S.T.H. (1977) Changes in the composition of maternal plasma, fetal plasma and fetal extra-embryonic fluid during gestation in the rat. J. Reprod. Fert. 51, 41-51.

Turbow, M.M. (1966) Trypan blue induced teratogenesis of rat embryos cultivated in vitro. J. Embryol. exp. Morph. 15, 387-395.

Wislocki, G.B., Deane, H.W. \& Dempsey, E.W. (1946) The histochemistry of the rodent's placenta. Am. J. Anat. 78, 281-345.

Received 11 April 1984 